
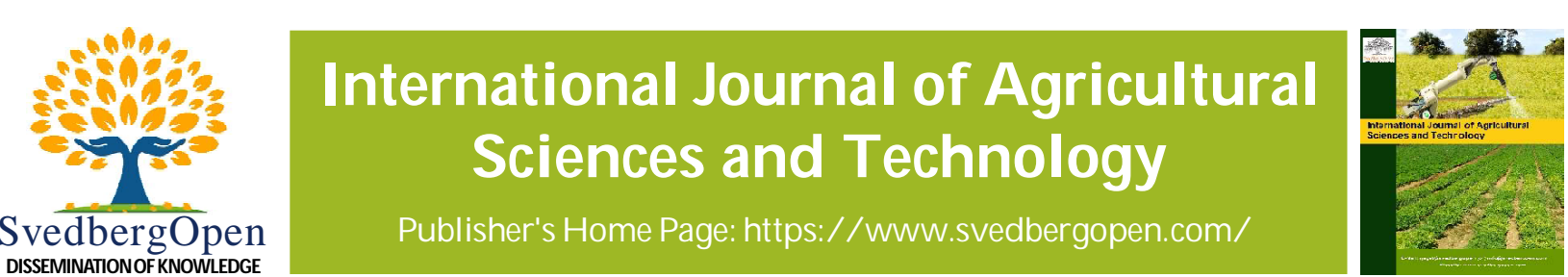

\title{
Covid-19 pandemic and beyond: utilizing digital ICT tools for transfer of agricultural innovations to farmers
}

\author{
Sharon. D. Samuel ${ }^{1 *}$ \\ ${ }^{1}$ Department of Agricultural Economics and Extension, Federal University, Oye-Ekiti, Nigeria. Email: sharon.samuel@fuoye.edu.ng
}

\section{Article Info}

Volume 1, Issue 3, August 2021

Received : 24 March 2021

Accepted : 15 July 2021

Published : 05 August 2021

doi: 10.51483/IJAGST.1.3.2021.1-3

\begin{abstract}
Agricultural Extension Services (AES) have been restricted due the Covid-19 guidelines set up by the World Health Organization (WHO) as well as the Nigerian Government, thereby limiting farmers' access to new innovations. The research utilized relevant literature on the subject to better understand how the coronavirus pandemic has affected AES and farmers. The study also suggests various means through which Digital tools can be utilized in order to propel agricultural production in time when Agricultural Extension Agents (AEAs) find it difficult to reach farmers. It was discovered that the pandemic creates opportunities for utilization of digital ICTs to contact farmers specifically when physical contacts are restricted. The utilization of Digital communication tools creates an enabling environment to access new agricultural innovations from any part of the world. AEAs can therefore transfer new innovations to farmers as well as other stakeholders in a challenging time as this and even beyond.
\end{abstract}

Keywords: Covid-19, Digital ICT, Agricultural Innovation Transfer, Farmers

(C) 2021 Sharon. D. Samuel. This is an open access article under the CC BY license (https://creativecommons.org/licenses/by/4.0/), which permits unrestricted use, distribution, and reproduction in any medium, provided you give appropriate credit to the original author(s) and the source, provide a link to the Creative Commons license, and indicate if changes were made.

\section{Introduction}

Coronavirus disease 2019 (Covid-19) has become a global pandemic that affects many, including developing countries with limited resources (Singhal, 2020). Covid-19 is caused by a type of influenza virus that suppresses the body's immune system so that the viruses can grow in the respiratory tissues and organs (Shi et al., 2020). According to The World Health Organization (WHO), the first cases of infection of a new coronavirus (2019-nCoV) were reported in Wuhan, China, on December 31, 2019 (WH0, 2020a). Since that time, the report of confirmed cases of infection with this new virus had an alarming growth now being the main global health problem, which is affecting the normal development of society and all its components (Siche, 2020). Nigeria was no exception as the first case of (2019-nCoV) was confirmed by the Nigeria Centre for Disease Control (NCDC, 2020). As with the rest of the world, the rate of new infections began to grow and a lockdown was introduced to curb the spread of the disease. The restriction of activities and the occurrence of a new virus began to affect people, including farmers in diverse ways. From past pandemics that the world has experienced, it has been shown that quarantines and panic have an impact on human activities and economic growth (Hanashima and Tomobe, 2012); but, the effect also occurs in agricultural activities.

* Corresponding author: Sharon. D. Samuel, Department of Agricultural Economics and Extension, Federal University, Oye-Ekiti, Nigeria. E-mail: Email: sharon.samuel@fuoye.edu.ng 
The utilization of digital Information and Communication Technology (ICT) for the transfer of new agricultural innovations to farmers seeks to determine and understand how the coronavirus pandemic has affected Agricultural Extension Services (AES) and farmers. The study also aims to suggest various means through which Digital tools can be utilized in order to propel agricultural production in a time when Agricultural Extension Agents (AEAs) find it difficult to reach farmers.

\section{Effects of covid-19 on agricultural extension services and farmers in Nigeria}

In Nigeria, smallholder farmers are the backbone of agricultural activities as well as food supply chains. According to (Olomola, 2007), Agriculture in Nigeria provides employment for $70 \%$ of the population. AES are responsible for technology transfer to farmers. According to Ajibola (2020), AES provide essential support for farmers and other value chain actors to meet new challenges they encounter in agriculture. The author further stated that since the advent of the corona crisis agricultural extension personnel now have limited interface with rural farmers and other chain actors. Due to movement restrictions and social distance regulations, farmers faced the challenge of accessing timely AES. These control measures have limited AEAs, face-to-face contact with rural farmers who may require AES; as a result, the food security and wellbeing status of these farmers may be threatened (Ajibola, 2020). In essence, there is the need for farmers to exploit Digital ICT tools in retrieving agricultural information to keep up with agricultural productivity.

\section{Exploiting digital Information Communication Technology in place of AES in Nigeria}

ICT is an incorporated system which entails use of computers, mobile telecommunication gadgets and television (Toluwase and Apata, 2017). ICTs also refer to the different link and infrastructures used in these processes, their applications and the numerous services these infrastructures render (Mansell and Wehn, 1998). These infrastructures include; internet, electricity, batteries and so on. Digital ICT refers to gadgets and supporting infrastructures that disseminate information to end users. In general terms, Digital ICTs involve the use of computers, mobile phones, emails, and supporting infrastructure (internet and mobile applications) to convey messages to an audience. Adoption and utilization of Digital ICTs offer a potential solution to mitigate the disruption in local food supply chains, especially during times of crisis, such as the pandemic (Mittal and Grimm, 2020).

Farmers require information in every stage of the agricultural process; from land preparation to planting, weeding, fertilizer applications, pests and diseases control, harvesting and even up to marketing level. According to (Ugande, 2017), the provision of the right and timely information to farmers also requires the use of appropriate communication channel. There is therefore the urgent need to switch from the conventional method of innovation transfer which is usually one-on-one contact to technology transfer trough Digital communication tools.

Digital ICTs have the ability to convey agricultural information to farmers in a timely and effective manner. Information regarding weather, new innovations, cost of inputs, fertilizer applications and even marketing opportunities can be received through Digital communication tools. They foster sharing of knowledge and information among extension agents and farmers. Due to the pandemic and restrictions, it has been challenging for AEAs to reach farmers. The utilization of mobile phone Apps such as WhatsApp, Facebook, Twitter and YouTube as well as Zoom App for Video Conferencing and Webinars for continuous and improved communication is therefore pertinent. Exploiting these channels of communication tools will ensure continuous and even better connection between farmers and AEA. The aforelisted ICT tools can solve problems of AES delivery to rural farmers due to several factors such as distance and cost.

\section{Conclusion}

The utilization of ICTs in sourcing for information have greatly increased during the Covid-19 pandemic. Undoubtedly, the pandemic exposes AES to numerous constraints, thereby limiting extension delivery. The pandemic, however creates opportunities for utilization of digital tools to contact rural farmers. All sectors harness the benefits of Digital ICTs for output optimization when physical contacts are restricted. Digital ICTs therefore possess great potential to sustain and improve farmers' production. Its utilization can propel faster access to innovations from any part of the world. With optimum utilization of Digital ICTs AEAs can transfer technologies to farmers as well as other stakeholders in a time as this and long after.

It is expected that the following recommendations will foster utilization of Digital communication tools to promote agricultural innovation transfer in order to record significant yield and income among farmers now and after the pandemic.

a. For improved communication of innovations, both government and Non-Governmental Organizations (NGOs) need to promote awareness and utilization of Digital ICTs among extension personnel, farmers and relevant stakeholders. 
b. Provision of necessary infrastructures for continuous and enhanced agricultural innovation transfer for extension personnel and farmers, as well as technical orientation and training.

c. Government and AEAs need to partner with relevant digital service providers to access tools suitable for information dissemination.

d. Effort should be made by Government to provide uninterrupted power supply and solar panels to rural farmers, while telecommunication agencies should ensure network/internet coverage to rural areas and subside purchase of mobile data.

e. Individuals as well as organizations should put more effort in developing mobile applications that will foster better communications between AEAs and relevant stakeholders as well as enhance transfer of innovations to farmers.

\section{References}

Ajibola. B. (2020). COVID-19 pandemic- Accelerating the use of digital agricultural extension tools in Nigeria. Unpublished research article. DOI: 10.13140/RG.2.2.12594.43206

Hanashima, M. and Tomobe, K. (2012). Urbanization, industrialization, and mortality in modern Japan: A spatio-temporal perspective. Annals of GIS, 18(1), 57-70.

Mansell, R. and Wehn, U. (1998). Knowledge Societies. Information technology for development. Oxford: Oxford University Press.

Mittal, A. and Grimm, J. (2020). ICT solutions to support local food supply chains during the COVID-19 pandemic. Journal of Agriculture, Food Systems, and Community Development, 10(1), 237-241.

NCDC (2020). https://ncdc.gov.ng/news/227/first-case-of-corona-virus- disease-confirmed-in-nigeria

Olomola, A.S. (2007). Strategies for managing the Opportunities and Challenges of the Current Agricultural Commodity Booms in SSA. African Economic Research Consortium (AERC). Nairobi, Kenya, AERC Senior Policy Seminar IX.

Shi, Y., Wang, Y., Shao, C., Huang, J., Gan, J., Bucci, E., Piacentini, M., Ippolito, G. and Melino, G. (2020). COVID-19 infection: The perspectives on immune responses. Cell Death \& Differentiation, 27, 1451-1451. Published March 23,2020.

Siche, R. (2020). What is the impact of COVID-19 disease on agriculture?. Scientia Agropecuaria, 11(1), 3-6. Facultad de Ciencias Agropecuarias Universidad Nacional de Trujillo, Peru.

Singhal, T. (2020). A review of Coronavirus Disease-2019 (COVID-19). Indian J. Paediatrics, 87, 281-286. https://doi.org/ 10.1007/s12098-020-03263-6

Toluwase, S.O.W. and Apata O.M. (2017). Use of ICTs as a source of information for improving agricultural productivity in South-West, Nigeria. International Journal of Agricultural Economics, 2(3), 50-54.

WHO - World Health Organization (2020a). Novel Coronavirus (2019-nCoV). Situation Report-1. January 21, 2020. 5 pp. available in: https://www.who.int/emergencies/diseases/novel-coronavirus-2019/situation-reports/

Cite this article as: Sharon. D. Samuel (2021). Covid-19 pandemic and beyond: utilizing digital ICT tools for transfer of agricultural innovations to farmers. International Journal of Agricultural Sciences and Technology. 1(3), 1-3. doi: 10.51483/IJAGST.1.3.2021.1-3. 